\title{
Resistance of Acanthamoeba to classic DNA extraction methods used for the diagnosis of corneal infections
}

\author{
P Goldschmidt, ${ }^{1}$ S Degorge, ${ }^{1}$ C Saint-Jean, ${ }^{1}$ H Year, ${ }^{2}$ F Zekhnini, ${ }^{1}$ L Batellier, ${ }^{1}$ \\ L Laroche, $^{3}$ C Chaumeil ${ }^{1}$
}

${ }^{1}$ Laboratoire du Centre National d'Ophtalmologie des Quinze-

Vingts, Paris, France;

${ }^{2}$ Laboratoire de Parasitologie

Mycologie, AP-HP Hôpital

Cochin, Université René

Descartes, Paris, France

${ }^{3}$ Service 5 du Centre National d'Ophtalmologie des Quinze-

Vingts, Paris, France

Correspondence to:

P Goldschmidt, Laboratoire du

Centre National d'Ophtalmologie des Quinze-Vingts, 28 rue de

Charenton, 75012 Paris, France; pablogol@aol.com

Accepted 3 October 2007

Published Online First

26 October 2007

\section{ABSTRACT}

Aims: Sensitive diagnosis of Acanthamoeba infections may prevent the clinical condition from becoming worse. In order to improve the diagnosis tool performances, we studied the implication of the DNA extraction procedures on the detection of Acanthamoeba by real-time PCR.

Methods: Acanthamoeba cysts mixed with a tag virus were processed according to different DNA preparation procedures: heat, Proteinase K (ProtK), alkali lysis, OlAmp $\mathrm{kit}^{\circledR}$, MagNA Pure (DNA Mini kit, MagNA Pure ${ }^{\circledR}$ Nucleic Acid isolation kit), ProtK+OIAmp and ProtK+MagNA Pure. Parasite-DNA loads were assessed by real-time PCR.

Results: The results show that the structures of Acanthamoeba cysts are resistant to reagents releasing the DNA from other cells and viruses. Heat, $\mathrm{NaOH}$ or ProtK did not allow the DNA extraction yields to be assessed or the inhibitors to be eliminated The OIAmp and the MagNA Pure partially improved the sensitivity of the PCR and eliminated the inhibitors. A significant increase in positive results was obtained with a ProtK treatment before commercial extraction kits.

ProtK+MagNA Pure yielded the highest rates of positivity. Conclusion: To minimise false negative results, the nucleic-acid based Acanthamoeba diagnosis requires, first, the efficient lysis of cysts (without affecting the DNA) to make the DNA available for extraction and amplification, and, second, the elimination of PCR inhibitors. A significant increase in the detection rates is obtained by adding a ProtK treatment $\left(10 \mathrm{~min}\right.$ at $\left.56^{\circ} \mathrm{C}\right)$ before the commercial procedures. ProtK+MagNA Pure yielded the best results in $30 \mathrm{~min}$, followed by ProtK+OIAmp (150 min).

Acanthamoeba are free-living organisms with a life cycle characterised by two stages, an actively dividing trophozoite developing hyaline pseudopodia and a quiescent cyst. Acanthamoeba are present in air, soil, dust, air-conditioning units, treated water, bottled water, swimming pools, dialysis units, eyewash stations, contact lenses and lens cases, and are considered among the most prevalent eukaryotic protozoa found in the environment. ${ }^{1-8}$

The trophozoites contain a trilaminar plasma membrane with spiny surface projections and a contractile vacuole in the cytoplasm, and their replication occurs by binary fission. ${ }^{8} 9$ Cyst formation is triggered under adverse conditions such as changes in temperature, $\mathrm{pH}$ and desiccation. ${ }^{10-15}$

The analysis of full-length nuclear small-subunit (SSU) rRNA gene allows Acanthamoeba to be classified into 15 genotypes (T1 to T15). ${ }^{16-18}$
Acanthamoeba can provoke sinusitis, cutaneous lesions, meningoencephalitis and keratitis in humans, ${ }^{19-23}$ and the majority of types causing keratitis belong to sequence T4. ${ }^{24-27}$

The nucleic acid amplification techniques (NAATs) generated a breakthrough in the history of parasitic infestation diagnosis, enhancing dramatically the sensitivity of the diagnosis methods and reducing the time needed by a lab to produce results. $^{28} 29$ The samples (biopsies, body fluids, tissue scraping and cells) should be processed (extraction) before NAATs in order to eliminate all the material (proteins, lipids, polysaccharides, anticoagulants, etc.) that may inhibit the DNA polymerases. The extraction of DNA consists in nucleic acid isolation, purification and concentration in an eluted product, and several methods have been adapted to viral, fungal, bacterial, chlamydial and parasitic PCR diagnosis. ${ }^{28-32}$

While evaluating the performances of different NAATs for corneal Acanthamoeba keratitis diagnosis, we observed significant differences if the results of the PCR calibration curves (Ct vs number of cysts) were plotted with suspensions of Acanthamoeba diluted before DNA extraction compared with those obtained with samples in which the DNA was extracted from a concentrated suspension and diluted thereafter. To understand these discrepancies, we planned a series of experiments aimed to study specifically for Acanthamoeba the efficiency of the different DNA extraction procedures routinely used in clinical microbiology settings.

\section{MATERIAL AND METHODS}

\section{Acanthamoeba preparations and nucleic acid extraction and purification}

All the experiments were carried out using the reference strain of Acanthamoeba T4 purchased from the American Type Cell Collection (ATCC). Trophozoites were cultivated in flasks containing $\mathrm{NaCl} 0.9 \%$ and killed E. coli. The growth was assessed by direct microscopic examination.

In order to induce the total transformation of the trophozoites into cysts, the suspensions were kept at $4^{\circ} \mathrm{C}$ for $48 \mathrm{~h}$. A cyst count was performed using the HMX Beckman haematology cell counter, double-checked by a microscopic count in a Malassez cell and diluted. DNA was extracted from suspensions containing $10^{3}, 10^{2}, 30,10$ and 3 cysts/ $\mathrm{ml}$. 


\section{DNA extraction}

Five microlitres of a whole virus preparation of Seal Herpesvirus (phHV) (gift from van Doornum, Department of Virology Erasmus MC, Rotterdam, The Netherlands) was added to $200 \mu \mathrm{l}$ of each cyst suspension before extraction (final concentration of approximately 1000-2000 viral particles per ml) to monitor the extraction processes and to assess the potential PCR inhibitors through the detection of delays in specific signals. $^{29}$

\section{Heat treatment}

Dilutions of the cyst suspensions $(200 \mu \mathrm{l})$ were mixed with $5 \mu \mathrm{l}$ of phHV and heated in a dry platform for $10 \mathrm{~min}$ at $95^{\circ} \mathrm{C}$, placed for $5 \mathrm{~min}$ at $-20^{\circ} \mathrm{C}$ and kept for $30 \mathrm{~min}$ at $20^{\circ} \mathrm{C}$. PCR was carried out immediately after.

\section{Proteinase K (ProtK) treatment}

Different concentrations of cysts suspended in $200 \mu \mathrm{l}$ of PBS were mixed with $200 \mu \mathrm{l}$ of ATL buffer (Qiagen, Courtaboeuf, France) $+40 \mu \mathrm{l}$ ProtK (Qiagen) $+5 \mu \mathrm{l}$ of phHV. The tubes were incubated at $56^{\circ} \mathrm{C}$ for 10,60 or $240 \mathrm{~min}$. The enzyme was inactivated at $95^{\circ} \mathrm{C}$ for $10 \mathrm{~min}$, and the tubes were cooled $\left(-20^{\circ} \mathrm{C}\right)$ for $5 \mathrm{~min}$. The temperature was then stabilised for $30 \mathrm{~min}$ at $20^{\circ} \mathrm{C}$, and PCR was carried out immediately thereafter. For further DNA extraction (OIAmp or Magna Pure), $200 \mu \mathrm{l}$ of the suspensions treated with ProtK was processed immediately afterwards, according to the QIAmp or the MagNA Pure kit instructions, and eluted in $50 \mu \mathrm{l}$ of DNA-free distilled water.

\section{$\mathrm{NaOH}$}

Different concentrations of cysts were resuspended in $100 \mu \mathrm{l}$ of $\mathrm{NaOH} 0.1 \mathrm{M}+5 \mu \mathrm{l}$ of phHV and incubated at $95^{\circ} \mathrm{C}$ for $5 \mathrm{~min}$. PBS $(200 \mu \mathrm{l})$ was added, and the tubes were cooled $\left(-20^{\circ} \mathrm{C}\right)$ for $5 \mathrm{~min}$. The temperature was stabilised for $30 \mathrm{~min}$ at $20^{\circ} \mathrm{C}$ before PCR or before the additional extraction procedures carried out with $200 \mu \mathrm{l}$ of the treated suspensions, according to the instructions provided by the OIAmp or the MagNA Pure manufacturers, and eluted in $50 \mu \mathrm{l}$ of DNA-free distilled water.

\section{OIAmp and MagNA Pure}

OIAmp ${ }^{\circledR}$ DNA Mini kit and MagNA Pure ${ }^{\circledR}$ Nucleic Acid isolation kit Different concentrations of cysts were resuspended in $200 \mu \mathrm{l}$ PBS $+5 \mu$ of phHV, and the DNA extraction was performed manually by the solid column-based extraction kit OIAmp ${ }^{\circledR}$ DNA Mini kit (tissue protocol) or by the MagNA Pure ${ }^{\circledR}$ Nucleic Acid isolation kit (Roche, Basle, Switzerland) with the MagNA Pure ${ }^{\circledR}$ Compact (Roche) automate. Nucleic acids were eluted in $50 \mu \mathrm{l}$ of DNA free distilled water. The time needed for the manual OIAmp procedure was $120 \mathrm{~min}$ with no additional equipment required and for MagNA Pure less than $28 \mathrm{~min}$, but required a specific dedicated robot.

\section{Primers and probe}

The sequences for Acanthamoeba real-time PCR were selected by using the primer Express 1.0 software ${ }^{\circledR}$ Applied Biosystems (Courtaboeuf, France) and blasted using the NCBI Blastn FAOs ${ }^{\circledR}$. These primers bracket a highly conserved sequence coding for the mitochondrial SSU rRNA in the vast majority of strains of Acanthamoeba. ${ }^{27}$
Real-time TaqMan ${ }^{\circledR}$ PCR assays

Two PCR reactions were carried out for each test in different microtubes in a final volume of $25 \mu \mathrm{l}$. The first tube used for the detection of Acanthamoeba DNA included the forward primer $(0.5 \mu \mathrm{M})$, the reverse primer $(0.5 \mu \mathrm{M})$ and the FAM-TAMRA Acanthamoeba probe $(0.4 \mu \mathrm{M})$ in $2 \times \operatorname{TaqMan}^{\circledR}$ Universal PCR Master Mix (MNL 430449, Applied Biosystems) and $12.5 \mu \mathrm{l}$ of the isolated DNA eluted in distilled water. The second tube included the phHV forward primer $(0.5 \mu \mathrm{M})$, reverse primer $(0.5 \mu \mathrm{M})$, the VIC-TAMRA phHV probe $(0.4 \mu \mathrm{M})$ and $12.5 \mu \mathrm{l}$ of the isolated DNA eluted in distilled water.

After incubation for $2 \mathrm{~min}$ at $50^{\circ} \mathrm{C}$ with uracil $N^{\prime}$-glycosylase, the microtubes were incubated for $10 \mathrm{~min}$ at $95^{\circ} \mathrm{C}$. The PCR cycling programme consisted in 50 two-step cycles of $10 \mathrm{~s}$ at $95^{\circ}$, and $65 \mathrm{~s}$ at $60^{\circ} \mathrm{C}$. The amplification and detection were carried out using the ABI Prism 7500 sequence detector system (Applied Biosystems). Real-time measurements were automatically registered, and the $\mathrm{Ct}$ were determined according to the fluorescence signal exceeding the background limit of 0.20 . The results (corresponding to the number of cysts) were corrected according to the volume of reactants used for the different extraction procedures.

\section{RESULTS}

The results presented in table 1 show that heating the samples for 10 min at $95^{\circ} \mathrm{C}$ or the treatment only with $\mathrm{NaOH}$ did not significantly enhance the Acanthamoeba detection levels. Treatment of samples for $10 \mathrm{~min}$ with $0.1 \mathrm{M} \mathrm{NaOH}$ did hydrolyse the phHV DNA, thus limiting the assessment of the nucleic acid extraction yields and of the inhibitors.

The treatment with ProtK slightly improved Acanthamoeba detection, but notably, no direct impact on the release of DNA was observed after prolonging the proteolysis for more than $10 \mathrm{~min}$ at $56^{\circ} \mathrm{C}$. In previous experiments, the overnight proteolysis of cysts at $4^{\circ} \mathrm{C}, 20^{\circ} \mathrm{C}$ and $37^{\circ} \mathrm{C}$ did not improve the detection rates (results not shown). In the present study, the treatment with ProtK may have slightly improved the detection of Acanthamoeba but was unable to eliminate the inhibitors. The proteolytic treatment for $4 \mathrm{~h}$ at $56^{\circ} \mathrm{C}$ did not eliminate the inhibitors in any of the samples, thus suggesting that the nature of the inhibitors was different from that of polypeptide-related structures.

The OIAmp and the MagNA Pure carried out according to the routine procedures were able to improve partially the sensitivity of the real-time PCR with almost equivalent performances. Both kits did eliminate the inhibitors from all the proteolytic mixtures (no delays in phHV Cts were observed), and it could be concluded that no parasites were in the samples testing negative. However, more than a threefold increase in the detection rates was obtained (with no inhibition in any of the reactions) if the samples were treated for $10 \mathrm{~min}$ with ProtK before carrying out the commercial DNA-extraction procedures. The cost of reactants was equivalent for both techniques, but the time required for ProtK+OIAmp and ProtK+MagNA Pure was $160 \mathrm{~min}$ (manual) and $30 \mathrm{~min}$ (robot), respectively. Positive results for suspensions containing very low cyst concentrations (3 cysts/ml corresponding to 0.15 cysts/reaction tube) were obtained in one test out of three only for samples pretreated with ProtK before MagNA Pure.

\section{DISCUSSION}

Acanthamoeba cysts are resistant to normal chlorination, extreme temperatures, most biocides and antibiotics, but not 
Table 1 Detection of Acanthamoeba by real-time PCR (results are indicated as + (positive) or - (negative) for each series of testing)

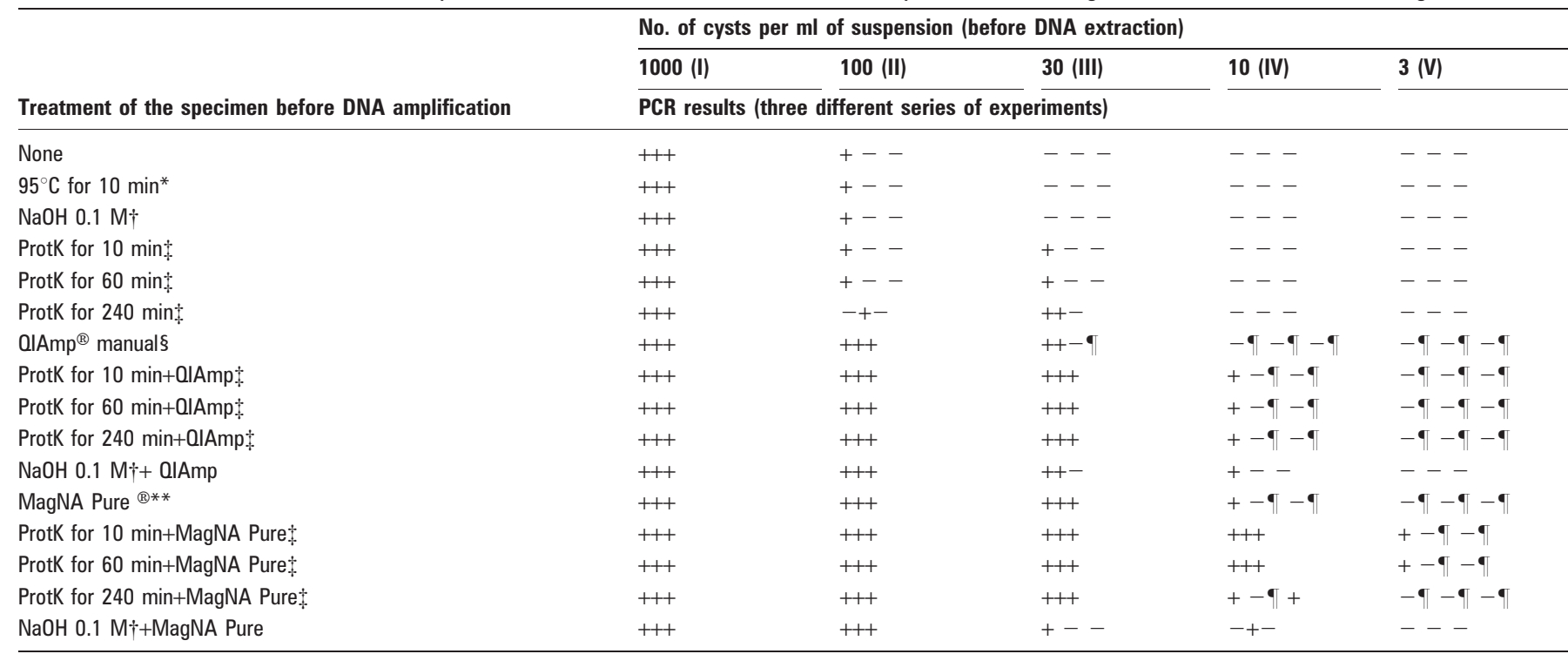

(I) to (V): concentrations corresponding to $50,5,1.5,0.5$ and 0.15 cysts/PCR reaction tube.

*Specimens in microtubes were placed in a dry heater for $10 \mathrm{~min}$ at $95^{\circ} \mathrm{C}$ and kept at $20^{\circ} \mathrm{C}$ for 30 min before amplification; †samples were treated with $\mathrm{NaOH}(0.1 \mathrm{M}$ final concentration) at $95^{\circ} \mathrm{C}$ for $5 \mathrm{~min} ; \mathrm{tProtK}$ at $56^{\circ} \mathrm{C}$ and heat inactivation at $95^{\circ} \mathrm{C}$; $\S$ OlAmp ${ }^{\circledR}$ DNA Mini Kit (Qiagen) — manual method; ${ }^{\top}$ true negative values (no delays were observed for the phHV Cts while comparing each result to those obtained with the controls for phHV, indicating the absence of inhibitors; samples showing delays or more than two Cts in comparison with controls were considered inhibited); ${ }^{* *} \operatorname{MagNA}$ Pure ${ }^{\circledR}$ (Roche)—automatic extraction robot.

to methylene oxide or autoclaving. ${ }^{33-37}$ The mature cysts are surrounded by two thick walls which form the exocyst and an endocyst that is closely apposed to the cell membrane. The nuclear membrane forms projections with vesicles bounded by double membranes, and very dense bodies of different sizes are found in the nucleus of every cyst. ${ }^{38} 39$ This high resistance of the cyst walls and the nuclear proteins that keep DNA condensed may explain the results that could have been obtained by using DNA-extraction procedures validated for viruses or bacteria if cysts are not properly lysed; it should be expected that the annealing of the primers and probes cannot be achieved because the parasite DNA is not available.

For micro-organisms different from cysts, several authors have shown the direct implication of DNA extraction on the performance of NAATs. Four DNA techniques, $65^{\circ} \mathrm{C}$ phenol, incubation at $97^{\circ} \mathrm{C}$, ProtK and OIAmp tissue kit, tested for the diagnosis of intracellular bacteria (Chlamydia trachomatis) showed that the QIAmp and the hot phenol extraction allowed the highest detection and that the digestion with ProtK and the heat denaturation were unable to eliminate inhibitors. ${ }^{40}$ For other bacteria, six methods (OIAmp Blood kit, Roche high PCR template, Puregene, boiling, glass beads/sonication and wash/ alkali/heat lysis) were evaluated in blood culture bottles infected with Gram-negative and -positive bacteria, yeast and fungi. The wash/alkali/heat lysis method was the most sensitive, reproducible and cost-effective method and removed the PCR inhibitors. ${ }^{41}$ For the diagnosis of Candida, Aspergillus and Cryptococcus sp., the extraction of DNA carried out using either the inhouse guanidium isothiocyanate-silica method ${ }^{42}$ or the OIAmp tissue kit yielded the same results if, before extraction, a minibead beating treatment was carried out to mechanically disrupt the yeasts. ${ }^{43}$ These results were confirmed by another study showing, for Candida albicans and Aspergillus niger, that OIAmp yielded the same sensitivity as one inhouse technique but shortened the duration of DNA extraction. ${ }^{44}$ For non-specific ophthalmic pathogens, a study carried out with Pneumocystis carinii sp. hominis mixed with human blood comparing the performances of three kits (GeneReleaser,
OIAmp, ReadyAmp, ProtK, and ProtK-phenol-chloroform treatment) showed that OIAmp was the most effective. ${ }^{45}$ For plasmodium, rapid boiling and the STIX provided the best results overall. ${ }^{46}$

All the trials described previously compared the different procedures according to the number of positive PCR results, but no systematic assessment of the DNA yields extracted from the samples was reported. To our knowledge, this is the first report showing-with the inclusion of an internal control (phHV serving a tag) - that the highly resistant structure of cysts may explain that the inability of the reagents used to extract the DNA from Acanthamoeba cysts leads to a false negative diagnosis. In the present study, the semiquantification of Acanthamoeba was determined simultaneously in the same tube with the DNA extraction yields and with the assessment of PCR inhibitors. Neither heating the cyst suspensions nor the ProtK treatment nor the commercial manual or automatic methods used separately produced satisfactory results. However, treatment with ProtK for $10 \mathrm{~min}$ before OIAmp or MagNA Pure, as used routinely for corneal infection diagnosis, ${ }^{28-}$ 32 dramatically improved the sensitivity of Acanthamoeba detection (10 and 3 cysts $/ \mathrm{ml}$, respectively).

The low performances of the Acanthamoeba diagnosis methods could be suspected to be due to a reduced avidity of the solid supports included in the commercial kits to bind the DNA and to the inefficiency of the DNA-elution procedures indicated by the manufacturers. Nevertheless, none of these hypotheses could be confirmed because the signals produced by the phHV were identical to the respective controls. Moreover, for all the samples extracted by OIAmp or MagNA Pure (but not for samples treated with $\mathrm{NaOH}$ or with ProtK), the phHV Cts were identical to each of the respective controls (phHV diluted in PBS and extracted), thus indicating that the negative results for Acanthamoeba were not the result of intrinsically low DNA-extraction capacities of the kits but signify that the DNA was not released from the cysts. After processing samples using the OIAmp or the MagNA Pure DNA extraction procedures, the Cts obtained for phHV with the samples testing negative for 
Acanthamoeba showed no inhibition. Finally, the addition of a 10-min Prot $\mathrm{K}$ pretreatment to the commercial procedures generated a higher number of positive results: the Acanthamoeba cyst DNA was prepared for further extraction processes, and the Taq polymerase inhibitors were eliminated. These two goals were achieved without affecting the assessment of the DNAextraction yields.

For the detection of Acanthamoeba the material representing the site where they may replicate and/or persist has to be adequately processed in the laboratory, and the diagnosis of this parasitic keratitis remains one of the most challenging issues in microbiology, due first to the extremely reduced biological material that can be obtained from patients presenting with small corneal lesions. Because the intense and repeated scraping of the cornea may trigger inflammatory responses with unpredictable consequences for the transparent structures of the eye surface, the laboratory cannot count with systematic double-checking by asking the ophthalmologists to carry out additional samplings. To minimise the risks of false negative results that may reduce the benefits of appropriate treatments, it should be noted that DNA-extraction procedures are not efficient in eliminating fluorescein, rose Bengal, lissamine green and local anaesthetics known to inhibit the Taq polymerase (PCR inhibitors): corneal specimens should be collected after properly rinsing the eye surface..$^{47} 48$ In addition, as shown in the present study, inappropriate procedures before conducting NAATs can lead to a false diagnosis of this infestation.

In conclusion, for the diagnosis of Acanthamoeba infestation by NAATs (real-time PCR or other), the evaluation of the different DNA extraction strategies shows that the highest detection rates $(10$ cysts $/ \mathrm{ml}$ ) could be obtained by treating samples containing cysts with ProtK before DNA is extracted by the classic methods (OIAmp DNA manual kit or MagNA Pure robot).

\section{Competing interests: None.}

\section{REFERENCES}

1. Marciano-Cabral F. Acanthamoeba spp. as agents of disease in humans. Clin Microbiol Rev 2003;16:273-307.

2. Mergeryan $\mathbf{H}$. The prevalence of Acanthamoeba in the human environment. Rev Infect Dis 1991;13(Suppl 5):390-1S.

3. Page FC. Re-definition of the genus Acanthamoeba with descriptions of three species. J Protozool 1967;14:709-24.

4. Barbeau J, Buhler T. Biofilms augment the number of free-living amoebae in dental unit waterlines. Res Microbiol 2001;152:753-60.

5. Barker J, Brown MR. Trojan horses of the microbial world: protozoa and the survival of bacterial pathogens in the environment. Microbiology 1994;140:1253-9.

6. Casemore DP. Free-living amoebae in home dialysis unit. Lancet 1977;2:1078

7. Page FC. A further study of taxonomic criteria for Limax amoebae, with descriptions of new species and a key to genera. Arch Protistenkd 1974:116:S149.

8. Preston TM, King CA. Amoeboid locomotion of Acanthamoeba castellanii with special reference to cell-substratum interactions. J Gen Microbiol 1984;130:231723.

9. Page FC. Re-definition of the genus Acanthamoeba with descriptions of three species. J Protozool 1967:14:709-24.

10. Penland RL., Wilhelmus KR. Comparison of axenic and monoxenic media for isolation of Acanthamoeba. J Clin Microbiol 1997;35:915-22.

11. Byers TJ. Growth, reproduction, and differentiation in Acanthamoeba. Int Rev Cytol 1979;61:283-338.

12. Mitro K, Bhagavathiammai A, Zhou OM, et al. Partial characterization of the proteolytic secretions of Acanthamoeba polyphaga. Exp Parasitol 1994;78:377-85.

13. Bowers B, Korn ED. The fine structure of Acanthamoeba castellanii (Neff strain). J Cell Biol 1969:41:786-805.

14. Byers TJ, Akins RA, Maynard BJ, et al. Rapid growth of Acanthamoeba in defined media; induction of encystment by glucose-acetate starvation. J Protozool 1980;27:216-19.

15. Chagla AH, Griffiths AJ. Growth and encystation of Acanthamoeba castellanii. J Gen Microbiol 1974;85:139-45.
16. Gast RJ, Ledee DR, Fuerst PA, et al. Subgenus systematics of Acanthamoeba: four nuclear 18S rDNA sequence types. J Eukaryot Microbiol 1996;3:498-504.

17. Stothard DR, Schroeder-Diedrich JM, Awwad MH, et al. The evolutionary history of the genus Acanthamoeba and the identification of eight new 18S rRNA gene sequence types. J Eukaryot Microbiol 1998;45:45-54.

18. Pussard M, Pons R. Morphologies de la paroi kystique et taxonomie du genre Acanthamoeba (Protozoa, Amoebida). Protistologica 1977:13:557-610.

19. Dunand VA, Hammer SM, Rossi R, et al. Parasitic sinusitis and otitis in patients infected with human immunodeficiency virus: report of five cases and review. Clin Infect Dis 1997;25:267-72.

20. Torno Jr MS, Babapour R, Gurevitch A, et al. Cutaneous acanthamoebiasis in AIDS J Am Acad Dermatol 2000;42:351-4.

21. Bhagwandeen SB, Carter RF, Naik KG, et al. A case of hartmannellid amebic meningoencephalitis in Zambia. Am J Clin Pathol 1975;63:483-92.

22. Fowler M, Carter RF. Acute pyogenic meningitis probably due to Acanthamoeba sp.: a preliminary report. Br Med J 1965;5464:740-2.

23. Patras D, Andujar JJ. Meningoencephalitis due to Hartmannella (Acanthamoeba). Am J Clin Pathol 1999;46:226-33, 345.

24. Schaumberg DA, Snow KK, Dana MR. The epidemic of Acanthamoeba keratitis: where do we stand? Cornea 1998;17:3-10.

25. Schroeder JM, Booton GC, Hay J, et al. Use of subgenic $18 \mathrm{~S}$ ribosomal DNA PCR and sequencing for genus and genotype identification of acanthamoebae from humans with keratitis and from sewage sludge. J Clin Microbiol 2001;39:1903-11.

26. Walochnik J, Haller-Schober E, Kolli H, et al. Discrimination between clinically relevant and nonrelevant Acanthamoeba strains isolated from contact lens- wearing keratitis patients in Austria. J Clin Microbiol 2000:8:3932-6.

27. Year H, Zamfir 0, Bourcier T, et al. Comparison of PCR, microscopic examination and culture for the early diagnosis and characterization of Acanthamoeba isolates from ocular infections. Eur J Clin Microbiol Infect Dis 2007:26:221-4.

28. de Boer JH, Verhagen C, Bruinenberg M, et al. Serologic and polymerase chain reaction analysis of intraocular fluids in the diagnosis of infectious uveitis. Am J Ophthalmol 1996;121:650-8.

29. van Doornum G, Guldemeester J, Osterhaus ADME, et al. Diagnosing herpesvirus infections by real-time amplification and rapid culture. J Clin Microbiol 2003;41:2576-80.

30. Morris DJ, Bailey AS, Cooper RJ, et al. Polymerase chain reaction for rapid detection of ocular adenovirus infection. J Med Virol 1995:46:126-32.

31. Goldschmidt $\mathbf{P}$, Rostane $\mathrm{H}$, Sow $\mathbf{M}$, et al. Detection by broad-range real-time PCR assay of Chlamydia species infecting human and animals. Br J Ophthalmol 2006;90:1425-9.

32. Van Gelder RN. Applications of the polymerase chain reaction to diagnosis of ophthalmic disease. Surv Ophthalmol 2001;46:248-58.

33. De Jonckheere $\mathbf{J}$, Van de Voorde H. Differences in destruction of cysts of pathogenic and nonpathogenic Naegleria and Acanthamoeba by chlorine. Appl Environ Microbiol 1976;31:294-7.

34. Khunkitti W, Lloyd D, Furr JR, et al. Acanthamoeba castellanii: growth, encystment, excystment and biocide susceptibility. J Infect 1998;36:43-8.

35. Turner NA, Harris J, Russell AD, et al. Microbial differentiation and changes in susceptibility to antimicrobial agents. J Appl Microbiol 2000;89:751-9.

36. Meisler DM, Rutherford I, Bican FE, et al. Susceptibility of Acanthamoeba to surgical instrument sterilization techniques. Am J Ophthalmol 1985:99:724-5.

37. Lloyd D, Turner NA, Khunkitti W, et al. Encystation in Acanthamoeba castellanii: development of biocide resistance. J Eukaryot Microbiol 2001;8:11-6.

38. Lasman M. Light and electron microscopic observations on encystment of Acanthamoeba palestinensis. J Protozool 1977;24:244-8.

39. Lasman M. The fine structure of Acanthamoeba astronyxis, with special emphasis on encystment. J Protozool 1982;29:458-64.

40. Freise J, Gérard HC, Bunke T, et al. Optimised sample DNA preparation for detection of Chlamydia trachomatis in synovial tissue by polymerase chain reaction and ligase chain reaction. Ann Rheum Dis 2001;60:140-5

41. Millar BC, Jiru X, Moore JE, et al. A simple and sensitive method to extract bacterial, yeast and fungal DNA from blood culture material. J Microbiol Meth 2001;47:255

42. Boom R, Sol CJ, Salimans MM, et al. Rapid and simple method for purification of nucleic acids. J Clin Microbiol 1990:28:495-503.

43. Löffler J, Hebart $H$, Schumacher $U$, et al. Comparison of different methods for extraction of DNA of fungal pathogens from cultures and blood. J Clin Microbiol 1997;35:3311-2.

44. Martin C, Roberts D, van Der Weide M, et al. Development of a PCR-based line probe assay for identification of fungal pathogens. J Clin Microbiol 2000;38:3735-42.

45. Rabodonirina M, Cotte L, Boibieux A, et al. Detection of Pneumocystis carinii DNA in blood specimens from human immunodeficiency virus-infected patients by nested PCR. J Clin Microbiol 1999;37:127-31.

46. Henning L, Felger I, Beck HP. Rapid DNA extraction for molecular epidemiological studies of malaria. Acta Trop 1999;72:149-55.

47. Goldschmidt $\mathbf{P}$, Rostane H, Saint-Jean C, et al. Effects of topical anaesthetics and fluorescein on the real-time PCR used for the diagnosis of Herpesviruses and Acanthamoeba keratitis. Br J Ophthalmol 2006:90:1354-6.

48. Seitzman GD, Cevallos V, Margolis TP. Rose bengal and lissamine green inhibit detection of herpes simplex virus by PCR. Am J Ophthalmol 2006;141:756-8. 


\section{LETTER}

A simple technique to administer mydricaine in needle-phobic patients

Subconjunctival mydricaine injections are used in routine practice in patients with uveitis to prevent the formation of permanent posterior synechiae. ${ }^{1}$ Mydricaine No 2 (Moorfields Eye Hospital formulation) contains a combination of $6 \mathrm{mg}$ procaine hydrochloride, $1 \mathrm{mg}$ atropine sulphate and $0.12 \mathrm{ml}$ epinephrine solution (1 in 1000). As it is normally injected subconjunctivally, this may prove difficult to administer to anxious, young patients, especially those who are needle-phobic. Belonephobia, the abnormal fear of sharply pointed objects, especially needles, affects up to $10 \%$ of the population and has implications for treatment and follow-up. ${ }^{2}$

We describe a very simple but effective method of administering mydricaine in needle-phobic, uveitic patients. We use two small sterile cotton wool pledgets which are fully soaked in $0.3 \mathrm{ml}$ mydricaine No 2 (which is usually used in adults $<75$ years of age). The patient receives topical anaesthetic drops into the eye. The lower lid is pulled downwards gently, and the first mydricaine-soaked pledget is placed securely with forceps into the inferior conjunctival fornix as the patient looks upwards (fig 1A). The second is tucked into the superior fornix under the upper eyelid as the patient looks downwards (fig 1B). Care should be taken to avoid abrading the cornea. The patient should be instructed to keep their eyes closed for 20-30 min. The pledgets can then be removed carefully. Topical steroid and mydriatic drops can subsequently be prescribed. The patient may be reviewed the following day to check the efficacy of the treatment. We have even successfully used this technique in a young Afro-Caribbean
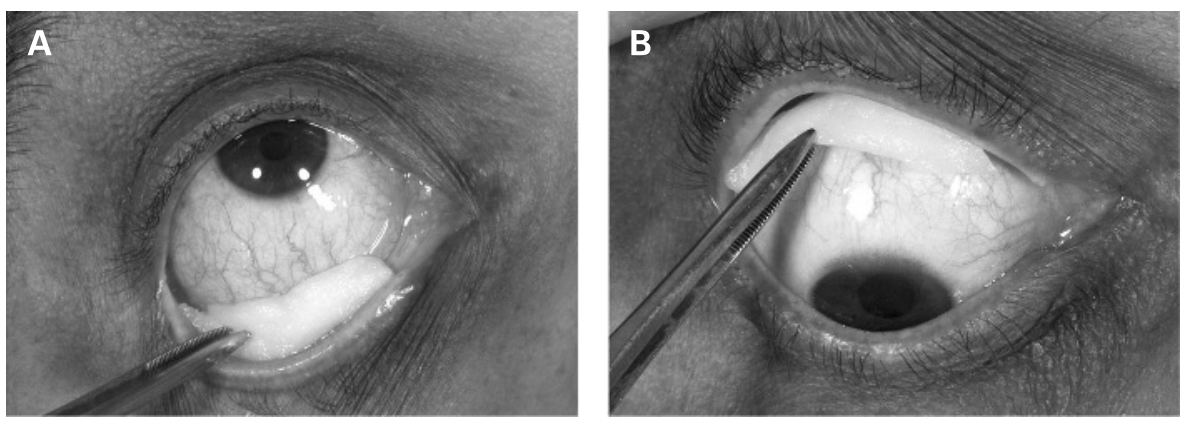

Figure 1 Mydricaine-soaked pledget placed with forceps into $(A)$ the inferior conjunctival fornix and $(B)$ the superior conjunctival fornix.

patient with black irides and severe fibrinous uveitis.

We propose using this pain-free technique in the outpatient setting for needle-phobic patients who require subconjunctival administration of a drug, to avoid the unnecessary use of local anaesthesia (with sedation) or general anaesthesia or the utilisation of valuable theatre time. It also avoids the complications of subconjunctival haemorrhage, chemosis and globe perforation. ${ }^{34}$ It may be worthwhile considering this technique in cooperative children (using mydricaine No 1) in order to avoid a general anaesthetic. We certainly advocate its use in the first instance, before considering further protracted interventions, as it is safe and effective. Indeed, this technique is a useful alternative to a subconjunctival injection for any patient, although the exact amount of drug absorbed through the conjunctiva is difficult to quantify, and also, it does not allow distribution of the drug in all quadrants, which would be useful in cases of $360^{\circ}$ of posterior synechiae. This would therefore be a limitation of the technique in needlephobic patients with $360^{\circ}$ of posterior synechiae, in whom it may not be as effective as subconjunctival injections in breaking the synechiae.

\section{W Rahman, C Pavesio}

Moorfields Eye Hospital, London, UK

Correspondence to: Miss W Rahman, Moorfields Eye Hospital, City Road, London EC1V 2PD, UK; waheedarahman2002@yahoo.co.uk

Acknowledgements: We thank Tony Swllivan and Girish Gosai for help with fig 1 .

Competing interests: None.

Accepted 5 October 2008

Br J Ophthalmol 2009;93:418. doi:10.1136/bjo.2008.149740

\section{REFERENCES}

1. Titcomb L. Eye disorders: mydriatic-cycloplegic and corticosteroids. Pharmaceutical Journal 1999;263:900-5.

2. Yim L. Belonephobia: a fear of needles. Aust Fam Physician 2006;35:623-4.

3. Petersen WC, Yanoff M. Subconjunctival anesthesia: an alternative to retrobulbar and peribulbar techniques. Ophthalmic Surg 1991;22:199-201.

4. Hay A, Flynn HW, Hoffman Jl, et al. Needle penetration of the globe during retrobulbar and peribulbar injections. Ophthalmology 1991;98:1017-24.

\section{CORRECTION}

doi:10.1136/bjo.2007.125898corr1

In the paper by Goldschmidt et al $(\mathrm{Br} J$ Ophthalmol 2008;92:112-15) the fourth author should be H Yera. 